\title{
The quality of corporate social responsibility of large coal mining companies in Russia
}

\author{
Elvira Zabneva, and Yulia Kuznetsova* \\ Branch of the Kuzbass State Technical University named after T.F. Gorbachev in Novokuznetsk city, \\ Ordzhonikidze Street, 7, 654000 Novokuznetsk, Russia
}

\begin{abstract}
The work proves the existence of two forms of social responsibility - constant and permanent, the level of which significantly differs among subjects of social activity (state, business and citizens). The authors introduced the term - "quality of corporate social responsibility" (QCSR) and key indicators for its assessment: 1) coverage of several segments of CSR implementation; 2) consistency in the implementation of CSR directions; 3) variety of directions within each segment; 4) information transparency of activities in terms of ensuring CSR. It was determined that the activities of coal mining companies are characterized by increased social obligations both in relation to their employees and the local population. The work carried out an expert assessment of the QCSR of the eight largest coal mining companies in Russia according to the proposed assessment indicators. It was revealed that only $25 \%$ of coal mining companies in terms of the aggregate of indicators can be attributed to companies with a high value of QCSR.
\end{abstract}

\section{Introduction}

The concept of "social responsibility" has become a part of our life. Taking into account a large number of studies of social responsibility, nevertheless, most often the concept is revealed as a conscious attitude of the subject of social activity to the established requirements, norms, values of social life. The variety of interpretations, types of social responsibility, is due to various social processes, the nature of the state policy, events in the life of the country.

Over a long period of meaningful transformation of social responsibility one can observe a different level of presentation of requirements for its provision by the state, citizens and business, and therefore from our point of view it is appropriate to talk about the presence of its constant and permanent forms. The state showing responsibility to its citizens, implements various types of impact on their positive (negative) activities. Ensuring the effective functioning of social sectors, monitoring compliance with social standards, implementing social programs, and so on - this is how the state participates in the life of society and responds to its problems. Within the framework of the identified forms of social responsibility the state responsibility undoubtedly belongs to the first of them, and the increase in responsibility occurs during periods unfavorable for society (Fig. 1).

${ }^{*}$ Corresponding author: acanaria2005@yandex.ru 


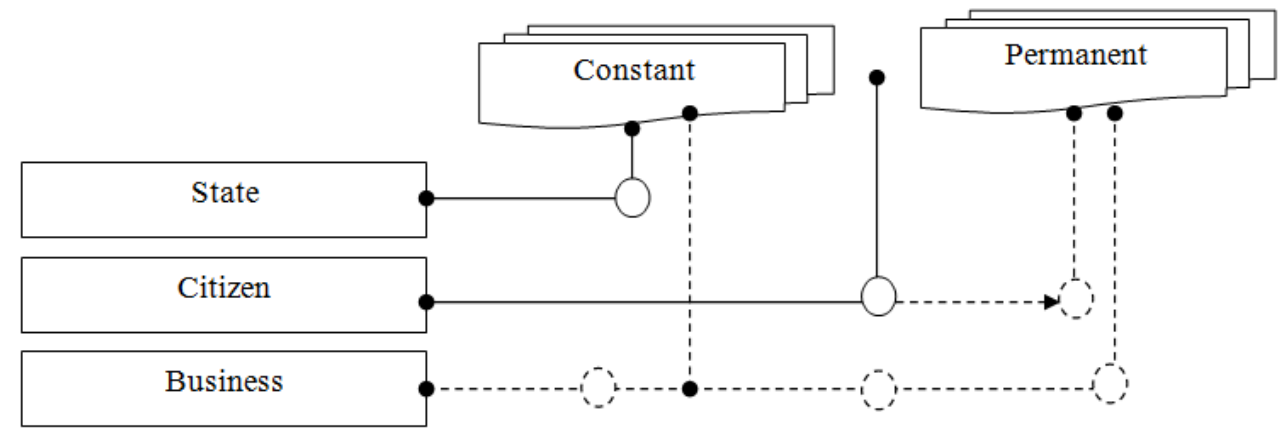

Fig. 1. Forms of social responsibility

Note: the solid line shows a definitive attribution to constant (permanent) forms of social responsibility; the dashed line - changing nature of attribution.

Personal (individual) social responsibility appears when the number of objects of human care increases and includes the close environment, local community, habitat or other objects [1]. At the beginning of the 20th century positive social responsibility was spoken of in many party documents, and its meaning was reduced to the fact that "every person, no matter what work he does, should be fully responsible for the task entrusted to him, carry it out with great conscientiousness, diligence and initiative; that everyone should work properly, live strictly observing the norms of socialist community" [2, p. 3]. At that time, the subjective side of positive social responsibility was highlighted, and personal social responsibility was recognized as key. Determining the attribution of personal social responsibility to one of the two forms it should be pointed out that most of all it tends to be permanent. The ambiguous nature is due to two reasons:

1) the permanent form is fully realized only when a person stably carries out some activity that benefits society (for example, volunteer activities, charitable activities, is a participant in environmental projects and programs);

2 ) in different periods of life, each person has a shift in emphasis on different types of social responsibility.

Business is a specific segment in terms of implementing social responsibility, since its activities in this direction are modified depending on numerous conditions and factors. If we talk about big business, then social responsibility is a separate, mandatory type of activity. Ensuring social responsibility of representatives of medium-sized businesses largely depends on the financial results of activities, as close as possible to the basic needs of employees. Small businesses in their overwhelming number are not yet able to fully implement all aspects of social responsibility due to insufficient income in this area. An exception is made by enterprises that must ensure the safety of their employees at a high level.

It is important to note that the concept of social responsibility of business is complemented by the characteristic "corporate" and there is a low degree of solidarity in its definition between domestic and foreign authors. Thus, experts of the European Commission define corporate social responsibility as "the responsibility of enterprises for their impact on society" [3]. D. Crowther, G. Aras give several definitions of various scales: it is the relationship between corporations, the government of countries and citizens, between a company and local community, between a company and its employees [4]. J. Tharp, P.D. Chadhury define corporate social responsibility as a new idea, according to which the corporate sector includes social and environmental issues in its strategies and enhances its role as a responsible business entity in the world [5]; A. D'Amato, S. Henderson, S. Florence as "the quality of the company's relationship with its employees 
and other stakeholders (customers, investors, suppliers, government officials, activists, communities) that have a decisive influence on its success, as well as to react to the conditions of competition "[6].

Speaking about domestic research we will give the following the most cited definitions: "the rational response of the company to the system of conflicting expectations of stakeholders, aimed at the sustainable development of the company" (Yu.E. Blagov) [7], "a new philosophy of business as a system of fundamentally new economic relations society, defined as an economic activity, focused on obtaining not only profit (income), but also to achieve the economic and social effect of this activity "(G.G. Bubnov, A.V. Semenov, K.S. Khachaturyan) [8], "the concept according to which organizations are responsible for the influence exerted by their activities on employees, shareholders, counterparties, local communities, on the state of the environment, while taking into account the interests of the community" (G.S. Klychova, A.R. Zakirova, A.R. Yusupova, A.S. Klychova) [9]. It seems that the most significant difference between corporate social responsibility in foreign and domestic definitions is a more practice-oriented nature in the first case, and conditionally strategic in the second. The conditionally strategic nature is highlighted because, mainly, only large companies fully implement all areas of social responsibility on a daily basis. Taking into account the existence of forms of social responsibility, the scale of implementation of corporate social responsibility in order to obtain an objective assessment of the activities of companies in the field of social responsibility, it is necessary to introduce such a concept as the "quality of corporate social responsibility" (QSCR), which is currently new.

\section{Method for researching the quality of corporate social responsibility}

The quality of corporate social responsibility (QCSR) is a set of characteristics of a company's activities that determine their ability to fully meet the needs of the local community and the company's stakeholders. The key indicators of QCSR can be:

1) coverage of several segments of the implementation of corporate social responsibility (for example, employees, business partners, consumers, local communities);

2) consistency of the implementation of areas of corporate social responsibility;

3) variety of areas of corporate social responsibility within each segment;

4) information transparency of activities in terms of ensuring the company's social responsibility.

The QCSR acquires particular importance for the companies that are city-forming, provide employment for the majority of the population, and significantly affect the life of local communities. Such companies are those that operate in the coal mining industry and have increased obligations both towards their employees and the population of the corresponding territory. The QCSR study was carried out for the 8 largest coal mining companies of the Russian Federation (the companies are distinguished by the indicator "Coal production in 2019, million tons"): JSC Siberian Coal Energy Company, JSC UK Kuzbassrazrezugol, PK EVRAZ, JSC HK SDS-Ugol, ALLTEK Group Sibanthracite, PAO Mechel, PAO Kuzbass Fuel Company, LLC Vostsibugol Company based on the expert method [10]. The result of the authors' expert assessment is presented as follows: the "+" sign reflects the high quality level of the indicator, "+ _-" - medium, "-" - low. Taking the sign "+" for 1 point, the sign "+ _-" for 0.5 points, the sign "-" for 0 points, the total quantitative value of the QCSR is calculated. The informational basis of the study was the data of social reporting, reports on sustainable development, and other profile information contained on the official websites of these companies. 


\section{QCSR analysis of large coal mining companies in Russia}

On the basis of an expert assessment the authors of the work compiled a table that clearly reflects the QCSR of large coal mining companies in Russia in terms of its key indicators (Table 1).

Table 1. QCSR of large coal mining companies in Russia

\begin{tabular}{|c|c|c|c|c|c|}
\hline \multirow[t]{2}{*}{ Company name } & \multicolumn{4}{|c|}{ Indicators of QCSR } & \multirow{2}{*}{$\begin{array}{c}\text { Total } \\
\text { value of } \\
\text { QCSR }\end{array}$} \\
\hline & $\begin{array}{l}\text { Coverage } \\
\text { of several } \\
\text { segments }\end{array}$ & $\begin{array}{l}\text { Consistency of } \\
\text { implementation } \\
\text { of directions }\end{array}$ & $\begin{array}{c}\text { Diversity of } \\
\text { directions }\end{array}$ & $\begin{array}{l}\text { Information } \\
\text { transparency }\end{array}$ & \\
\hline $\begin{array}{lr}\text { Siberian } & \text { Coal } \\
\text { Energy } & \text { Company } \\
\text { JSC } & \\
\end{array}$ & + & + & + & + & 4 \\
\hline $\begin{array}{l}\text { "UK } \\
\text { «Kuzbassrazrez- } \\
\text { ugol» JSC } \\
\end{array}$ & + & - & +- & +- & 2 \\
\hline PK "EVRAZ" & + & + & + & + & 3 \\
\hline SC HK "SDS-Ugol" & - & - & - & - & 0 \\
\hline $\begin{array}{l}\text { ALLTEK } \\
\text { "Sibanthracite" } \\
\text { group }\end{array}$ & + & - & + & +- & 2,5 \\
\hline Mechel PAO & + & - & + & +- & 2,5 \\
\hline $\begin{array}{l}\text { "Kuzbass Fuel } \\
\text { Company" PJSC }\end{array}$ & + & - & + & - & 2 \\
\hline $\begin{array}{l}\text { Company } \\
\text { "Vostsibugol" LLC }\end{array}$ & - & - & - & - & 0 \\
\hline
\end{tabular}

JSC SUEK is a company that fully meets all the indicators of QCSR. The principles of corporate governance developed in the company are laid down in the basis of corporate social responsibility: equal treatment of all shareholders of the company, information transparency, compliance with ethical standards of doing business, and ensuring decent working conditions for employees [11]. Social responsibility is implemented in all subjects of the internal environment of the organization. The areas of social responsibility implementation are especially broad in the HR and Environment segments. Since 2001 information on the areas of ensuring social responsibility has been placed in the public domain on the official website of JSC SUEK. For each direction quantitatively measurable indicators are presented.

JSC "MC "Kuzbassrazrezugol" is an enterprise of the raw materials division of the Ural Mining and Metallurgical Company. A separate section of the company's official website is devoted to an overview of areas of social responsibility - social and economic cooperation, support for culture, support for sports, charity [12]. In other words, the company singles out the local community as objects of social responsibility. The low quality score in terms of "consistency in the implementation of directions" is explained by the lack of information on the areas of corporate social responsibility on the official website.

PK EVRAZ is a company, one of the goals of which is to implement a responsible approach to social obligations based on international experience in promoting the development of the local economy and providing support to communities in the regions of its presence. The company is one of the few that have a Corporate Strategy as well as a document approved by the EVRAZ Board of Directors on the main directions of social investments [13]. Ensuring a constructive dialogue with local communities, respect for the peculiarities and traditions of the peoples inhabiting the regions of presence are just a few of EVRAZ's corporate social responsibility principles. For many years, the company has been implementing corporate volunteering, and in terms of work with the company's 
personnel, notable from both conceptual and substantive points of view is the Policy for ensuring socio-cultural diversity and taking into account the individual characteristics of employees.

AO HC SDS-Ugol, which is an industry holding of the Siberian Business Union, does not provide any information about segments and areas of corporate social responsibility, although a similar section on the official website is stated [14].

ALLTEK Sibanthracite Group is the largest producer of metallurgical coal in Russia [15]. Segments of social responsibility are: "Support of the regions", "Our value is people", "Environmental protection". Sales directions and quantifiable indicators are described in detail for each segment. However, due to the lack of information for a number of years, it is difficult to talk about the constancy of the implementation of the selected areas.

PAO Mechel unites more than 20 industrial enterprises operating in a single production chain. Segments of activity in the sphere of social responsibility cover non-state pension provision, health improvement and recreation of employees, sports events, include taking care of employees' families, work with trade unions and development of enterprises presence regions [16]. The indicated segments are rather poorly disclosed in terms of the realized directions and quantitative indicators.

PJSC Kuzbass Fuel Company is one of the largest producers and exporters of thermal coal in Russia. The company allocates significant funds for the implementation of social programs in the Kemerovo region where coal mining is carried out [17]. There is no separate section on corporate social responsibility on the company's official website; all information is located in the "Company" section. The management discloses the social responsibility of the company in the following 6 theses:

1) production of high-quality products in demand;

2) creation of new jobs in the region;

3) implementation of social programs for personnel;

4) providing support to the spheres of culture and education;

5) concern for the preservation of the environment;

6) provision of sponsorship and charity.

However, there are no indicators to assess the quality and effectiveness of these activities.

LLC "Company "Vostsibugol" closes the eight analyzed companies. It is one of the long-standing and stable companies operating in the coal mining market, but the description of activities in the field of social responsibility is completely missed [18].

\section{Conclusions}

QCSR study results classification of the largest coal mining companies revealed the following:

1) segments of corporate social responsibility are distinguished from a wide to a narrow range (from helping regions to implementing corporate programs for employees);

2) large coal mining companies have no unity in identifying segments and areas of activity in the area of social responsibility;

3) some kind of stability in the implementation of social responsibility can be tracked at only a small part of coal mining companies;

4) the level of information transparency about is at a low level.

Thus, on the totality of indicators of the QCSR only $25 \%$ of companies can be attributed to the group with a high value of the QCSR. 


\section{References}

1. T. L. Sudova, Individual social responsibility, http://www.vectoreconomy.ru/

2. V. V. Klochkov, News of higher educational institutions. Jurisprudence, 3 (1987)

3. Corporate Social Responsibility and Responsible Business Conduct. European Commission, https://ec.europa.eu/

4. D. Crowther, G. Aras, Corporate social responsibility (2010)

5. J. Tharp, P. D. Chadhury, Corporate social responsibility: What it mean for the project manager (2008)

6. A. D'Amato, S. Henderson, S. Florence, A Guide to Leadership Tasks and Functions, 102 (2009)

7. Yu. E. Blagov, Russian Management Journal, 17 (2004)

8. G. G. Bubnov, A.V. Semenov \& K. S. Khachaturian, Transport business of Russia, 106 (2011)

9. G. S. Klychova, A. R. Zakirova, Bulletin of Kazan State Agrarian University, 130 (2018)

10. Portal eRUDA.ru, www.eruda.ru/

11. Official site of the company JSC «SUEK». Social reporting, http://www.suek.ru/

12. Official site of the company JSC "MK «Kuzbassrazrezugol», https://www.kru.ru/

13. EVRAZ official website. Sustainable development, https://www.evraz.com/

14. The official website of the company JSC HK «SDS-Ugol», sds-ugol.ru/about-thecompany/

15. Official site of ALLTECH «Sibanthracite» Group, http://www.sibanthracite.ru/

16. Official website of PAO Mechel, https://mechel.ru/about/

17. Official website of PJSC «Kuzbass Fuel Company», http://ktk.company/

18. Official website of LLC Vostsibugol Company, https://www.kvsu.ru/ 